Anna Achmatowicz-Otok

\title{
CHANGES OF HOMOGENEITY OF AUSTRALIA POPULATION OVER THE YEARS 1971-1981
}

The Commonwealth of Australia is a multi-ethnic country. The number of original Australians, Aborigines, two hundred years ago estimated at approximately 400 thousand people, at present amounts to a little over 40 thousand people of pure blood. The remaining, greater part of people that live in Australia at present is of foreign; they came here from all over the world in different ways and at different time. ${ }^{1}$

The percentage of people of extra-Australian birth, settled in this country, in 1971 amounted to 20.2, whereas in 1981 it grew up to 21.8 of the whole of inhabitants of this country; children of those immigrants born after their parents had come to Australia are classified by the local statistics as Australians.

Distribution of Australian inhabitants born in other countries over the territory of the Commonwealth of Australia is irregular, the composition of local communities being much differentiated-beginning with relatively homogenous communities over the agricultural areas ending with multi-ethnic ones in other regions.

In order to present the ethnic differentation of people living in Australia the so called ethnic coherence (homogeneity) index has been made use of. The index, introduced into Polish geographical literature by E. Piasecki $(1964)^{2}$, is calculated according to the following formula:

\footnotetext{
1 Terms "groups" and "ethnic groups" are used changeably following the Census of Population and Housing 1971 and 1981, Australia.

${ }^{2}$ Piasecki, E., „Charakterystyka liczebności ludów świata i próba analizy zawartości etnicznej terytoriów" (Characteristics of the number of world's population and a tentative analysis of territories' ethnic homogeneity), Czasopismo Geograficzne, 1964, Vol. XXXV, fasc. 1, pp. 73-85.

${ }^{3}$ Piasecki, E., „Gęstość zaludnienia a zróżnicowanie etniczne” (Density of population and ethnic differentiation), Przegląd Geograficzny, vol. XLIX, fasc. 1, 1977, pp. 119-126.
} 


$$
S=\frac{\sum_{i=1}^{n} \cdot l_{i}^{2}}{L^{2}} \cdot C
$$

where:

$l^{i}$ - size of particular ethnic groups,

n - number of ethnic groups,

$L$ - total number of country's population,

$C$ - constant number, usually 100 .

The analysis of homogeneity of people of Australia has been made on the basis of the Census Population and Housing data of 1971 and 1981 published, by the Bureau of Census and Statistics, Australia.

The 1971 data have been elaborated in their territorial aspect exact to Lecal Government Areas, Statistical Divisions and particular states. The 1981 data made it merely possible to carry out analysis exact to the states.

The calculations resulted in people's ethnic homogeneity index for all Local Government Areas. The closer to 100 the index's value is, the greater is the ethnic homogeneity of the inhabitants of the researched region. Thus indexes exceeding 90 are characteristic of a decidedly homogenous society whereas those below 50 indicate occurrence of a multiethnic society.

The applied definitions should be treated as conventional, useful at ethnic research based upon statistics presenting population according to the native country. In research based upon statistics that comprise ethnic minorities according to other criteria (e.g. partners' native country or cultural self-determination of belonging to the native country of ancestor of the inquired) the above definitions may be subject to changes.

According to the ethnic differentiation of people over the Australian continent, the two distincly different parts can be distinguished: the eastern and the western one. The division line runs from Port Augusta in the state of South Australia on the Spencer Gulf towards the eastern border of Northern Territory, then along it towards the North to the Gulf of Carpentaria. Inhabitants of the territories east of this division line are characterized by great homogeneity. Over most of the area the ethnic coherence index exceeds 90, which indicates a decidedly homogeneous, Australian character of the people who live there. This pertains to both the maritime territories and the continent's interioragricultural and stock-farming areas. A slightly lower population homogeneity was recorded in the LGAs - both seaside and those in the continent's interior - on whose territories mining activities are going on; they are connected with production of metal ores and rock raw materials, chiefly non-energetic, on a small scale. The ethnic homogeneity index in those 
LGAs ranges from 80 to 90 , which points out quite a homogenous character of people who live there, population of Australian birth prevails among them.

Occurrence of numerous minority groups is characteristic of the mining centres in the continent's interior connected with production of energy-consuming raw materials of strategic importance, as well as the LGAs, where extensive water power engineering works are being carried on. Here the index ranges from 60 to 70 . However, those are small and scarcely occurring areas.

The lowest ethnic homogeneity index over the eastern zone occurred in great metropolises: Sydney, Melbourne, Adelaide and Canberra. Those cities were inhabited by multi-ethnic population, the index's value ranging from 50 to 60 .

The same value was recorded in hard- and brown-coal-mining centres: in Wollongong in New South Wales and in Latrobe Valley (Morwell) in Victoria. All the above-mentioned cities and mining centres are densely inhabited by Polish immigrants.

A different situation was observed west of the said division line. Dense areas of a decidedly ethnically homogeneous population hardly occur here. They are to be found - their areas being rather small-in the agricultural regions on the Spencer Gulf in the southernmost part of the state of South Australia west of the above-mentioned division line. The ethnic homogeneity index amounted here to $80-90$ or over 90 .

Another area of Australia's western part inhabited by homogenous population are the agricultural regions of the state of Western Australia that belong to Northern Agricultural, Central Agricultural and Southern Agricultural Statistical Divisions-index of $80-90$ was recorded here.

Besides, ethnically homogenous Australian society live in two remote from each other LGAs situated in the interior. These are: Halls Creek in Kimberly Statistical Division and Wiluna in Central Statistical Division.

The remaining area west of the above division line is inhabited by population of smaller homogeneity: multi-ethnical in the areas of intensive mining activities situated in the interior, and decidedly multi-ethnical in such LGAs as Port Hedland, Roebourne and Tableland (Pilbara Statistical Division, Western Australia), where mining activities, building industry and transport were very intensive, as well as in such as Whyalla and the Unincorporated Area in South Australia connected with ore and its processing. The ethnic homogeneity indexes amounted here respectively to 42 and 45 .

Also the greatest metropolis of this part of Australia, Perth, was inhabited by a very ethnically differentiated population - the index amounted here to 50 .

Characteristics of ethnic differentiation of people of Australia according to the states have been carried out for the 1971 and 1981. Towards 
the end of the decade under study the percentage of people of Australia born beyond its borders grew by 1.6. This resulted in the fall of homogeneity of Australian population over most of the territory (Table 1).

Table 1

Ethnic homogeneity index according to states in 1971 and 1981

\begin{tabular}{|c|c|c|c|}
\hline Statc & 1971 & 1981 & Difference \\
\hline ACT Canberra & 57 & 58.3 & +1.3 \\
\hline Victoria & 60 & 58.6 & -1.4 \\
\hline New South Wales & 66 & 62.1 & --3.9 \\
\hline Western Australia & 50 & 53.5 & +3.5 \\
\hline South Australia & 60 & 59.6 & -0.4 \\
\hline Queensland & 77 & 71.4 & -5.6 \\
\hline Tasmania & 80 & 79.0 & -1.0 \\
\hline Northern Territory & 65 & 61.1 & -3.9 \\
\hline
\end{tabular}

Greatest homogeneity drops were observed in Queensland, as well as in densely populated New South Wales and at the same length in almost uninhabited Northern Territory.

Statistical characteristics of population in 1971 showed that most numerous groups of people settled in Australia were made up of people born in Australia, Italy, Grecce, Yugoslavia, Germany, Great Britain and Ireland, Netherlands. New Zealand, Poland and Malta.

In 1981 greatest population groups were made up of people born in Australia, Great Britain and Ireland, Italy, New Zealand, Yugoslavia, Greece, Germany, Netherlands, Poland, Malta and Lebanon. Within the decade 1971--1981 considerably grew the group of Australian inhabitants born in New Zealand $(+119.6 \%)$, the number of people born in Greece $(-8.5 \%)$, Italy $(-4.7 \%)$, Netherlands $(-3.3 \%)$, Poland $(-0.5 \%)$, Germany $(--0.1 \%)$ decreased. Besides population growth came about within groups of people born in Lebanon $(+104.9 \%)$, Yugoslavia $(+14.9 \%)$, Australia $(+11.8 \%)$, Malta $(-6.1 \%)$ and Great Britain together with Ireland $(+4.0 \%)$, as well as among those born in Oceania.

By and large stagnation in the inflow of immigrants from Europe to Australia is noticeable in the years 197I-1981 (Table 2). At the same time within the decade under study, there occurred intensified and whatsoever rapid inflow of immigrants born in Asia and Oceania, and also slightly slower, though, inflow from North and South America. The hithero described trends undoubtedly result from the change of immigration policy of Australia's federal government, abandoning the conventional law "White Australia" towards the prospective emigrants, 
Table 2

Australian inhabitants according to place of birth

\begin{tabular}{l|r|r|r}
\hline \multicolumn{1}{|c|}{ Birthplace } & \multicolumn{2}{c}{ Population number } & $1971 \ldots$ \\
\cline { 2 - 5 } & \multicolumn{1}{c}{1971} & \multicolumn{1}{c}{1981} & \\
\hline & $10,266,431$ & $11,570,573$ & 112.7 \\
Australia and New Zealand & $2,196,478$ & $2,223,077$ & 101.2 \\
Europe & 167,426 & 371,591 & 221.9 \\
Asia & 61,935 & 90,237 & 145.6 \\
Africa & 55,752 & 96,245 & 172.6 \\
North and South America & 7,816 & 36,130 & 462.2 \\
Oceania & $12,755,638$ & $114,576,330$ & 114.2 \\
Australia total & & & \\
\hline
\end{tabular}

Characteristic are places on the Earth from which new intensive emigration streams are directed to Australia. These are chiefly areas of war, areas of political and social unrest, as well as areas where the standard of living is lower, despite considerable economic stabilization. If the discussed trends of immigrants' inflow directions keep on over the decades to come, this may result in significant changes in the ethnic, cultural and race composition of the Australian continent. 
